\title{
Integral Estimate of the Added Value of Agricultural Crops in the Synergetic Agriculture on the Example of Vicia Faba (Vicia faba L.)
}

\author{
Qi Zhao ${ }^{1}$, Sergei V. Cherkasov², Aleksei P. Avdeenko ${ }^{3 *}$, \\ Larisa N. Kondratenko ${ }^{4}$, Alexey Y. Mikhaylov ${ }^{5}$ \\ ${ }^{1}$ School of Life Sciences, Zhengzhou Normal University, Zhengzhou, China
}

${ }^{2}$ Kuban Branch of V.M. Gorbatov Federal Research Center for Food Systems of RAS, Krasnodar, Russia ${ }^{3}$ Department of Agriculture and Storage Technologies for Crop Products, Don State Agrarian University,

Persianovsky, Russia

${ }^{4}$ Department of Advanced Mathematics, Kuban State Agrarian University named after I. T. Trubilin, Krasnodar, Russia ${ }^{5}$ Research Center of Monetary Relations, Financial University under the Government of the Russian Federation, Moscow, Russia

Received: 9 October 2020

Accepted: 25 December 2020

\begin{abstract}
The objective of the research is to estimate the efficiency of the use of different varieties of vicia faba (Vicia faba L.) in permaculture designs for supply growth in agricultural commodity market. The main purpose of the article is to distinguish which varieties of legumes can be effectively grown in the temperate climate zone and whether there is an advantage in organic farming cultivation. The researches were carried out in 2014-2019 on the territory of the Moscow region (the Russian Federation) in Educational Experimental Farm. 23 varieties of the broad bean from the collection of All-Russian Scientific-Research Institute of plant breeding and seed production (ARSRIPBSP) (Moscow) as well as foreign breeding was selected. There were a standard method of farming (control) and plots where a permaculture (experimental group) is applied. For the period 2014-2019 the total number of plots made up 1380, by 690 in each experimental and control groups. We demonstrated that within the conditions close to the natural ones, some varieties of beans can produce the same yield as under standard farming. This article first presents comparative results of the research related to the crop yield and other properties of different varieties of the broad bean in the temperate climate within organic farming.
\end{abstract}

Keywords: broad bean, crop yield, organic farming, permaculture, Vicia faba L.

*e-mail: avdeenkoalex@rambler.ru 


\section{Introduction}

To solve the issue of food supply under the evergrowing world population is one of the most important challenges of $21^{\text {st }}$ century [1]. The agriculture is subject to solve the issue. In the framework of the agricultural intensification in the whole world, there is the increase in the production of mineral fertilizers. Only nitrogenbased fertilizers, which are more used, are annually produced over 70 million tons in the world. The average volume of the nitrogen-based fertilizers planted per unit area ranges from 125 to 250 tons per 1 ha. Almost one quarter of the volume gets into wastewater or into the atmosphere, that is, the latter is not absorbed by plants and microorganisms. This fact testifies that such means of artificially increasing of the crop yield is rather ineffective [2]. Moreover, part of the nitrates gets into the groundwater and plants, worsening their quality parameters. With excessive use of mineral and organic fertilizers, the imbalance occurs in the microflora of soils; as a result, its significant part is destroyed. As you know, this negative effect starts to affect when more than $15 \mathrm{~kg}$ of active substance is applied per 1 ton of fertilizer; in case of more than $20 \mathrm{~kg}$, the soil degumification occurs [3]. Given the widespread use of such technologies, as expected, we can affirm that global deterioration of soil quality and its crop yield takes place. Thus, the search for other farming means, less consuming and more secure, is performed.

Within all diversified farming means, one of the most promising new methods is organic farming [4]. Organic farming is constantly increasing production volumes around the world, over the past 10-15 years the increase in ten times has been recorded. With such rapid development, already in 2020, there will be increase in organic farming by $20 \%$ annually. Among sociocultural factors we can state that the massive transition to organic farming will contribute to a partial outflow of the population to the countryside, contrary to the prevailing trend of global urbanization. Organic farming is based on small farms that grow relatively small amounts of crop yields [1].

The essence of organic farming is to design and create steady closed ecosystems, inside of which the development of properties of one variety will ensure the development of other varieties. In some sources such type of organic farming is called permaculture. A common property of the permaculture and organic farming is the rejection from fertilizers and chemicals. At the same time, the permaculture is, to a great extent, a philosophical approach [5]. The closeness of the ecosystems is rather a conditional concept, in the framework of biosphere there are no closed systems. The wood or marshland, considered as a model in permacultures (and organic farming systems as a whole), is the ecosystem, which comprises a certain quantity of varieties of plants, animals, mushrooms, and bacteria that are in stable competitive or mutualistic relations, and are able to coexist with each other for a long time. The purpose of creating agriculture ecosystems is precisely such sustainability [6].

The effectiveness of organic farming is determined by factors such as production costs, as well as the productivity of animals and crops. We should say that in organic farming less energy is consumed when standard and environmental methods are collectively used. Chemicals are not used at all. Despite the fact that the yield of eco-crops is lower on the average than using traditional agricultural methods, this is compensated by savings in herbicides, pesticides, and energy sources. The lack of standard agricultural methods will become obvious in a long-term perspective, when high crop yield is sharply dropping due to soil depletion, from which the decrease in the economic effect is expected. At the same time, organic products are on average by 25-35\% more expensive than "standard" analogues [7].

Most advanced countries of the world are already massively using organic farming technologies. They are countries of the European Union, USA, Japan, Australia, and Canada. The advantages of organic farming include also the preservation of natural wealth, as well as high quality products. The efficiency of organic farming is emphasized by the constant implementation of various scientific developments. The benefits of such type of farming are obvious to both developed and developing countries. But still, regardless of the expansion of organic farming in human life, there are some issues that have not been fully studied and disclosed, in particular, the efficiency of cultivation and yield of legumes with this management approach to the farming in regions with a temperate climate [8]. At least half of all farmlands in the world is in temperate regions. So, to obtain legume crop is necessary to conduct a comparative analysis of various varieties of legumes in a temperate climate.

The transition to organic farming on a massive scale is currently impossible, because restoration processes in soils after intensive agriculture, using fertilizers, will take more than one year. In addition, researches are necessary on strategically important crops, their fertility and other qualities within organic farming in different climatic regions of our planet.

Broad bean (Vicia faba L.) is one of the most widespread representatives of agricultural crops worldwide, belonging to the legume family (Fabaceae). The fruits of this plant are used as a protein component in the human diet, and the green part (or tops) as one of the components in animal nutrition. It is also important that the dried stems of the bean can be used as fertilizers of natural origin. The bean seeds contain amino acids, which determine its nutritional value specifically for human beings. Regarding the use of bean stalks as fertilizers, we should pay attention to the fact that, when they are applied, more than $150 \mathrm{~kg}$ of assimilated nitrogen remains per 1 ha of territory [9].

However, the breeding of new varieties of beans often does not take into account the fact that, along with nutrients in beans, anti-nutrients can also be 
formed. These substances (tannins, vicine, convicin) reduce the quality properties of seeds, and also critically increase the cost of maintaining the nutritional value of animal feed. Legumes are an important part of permaculture communities because of their ability to keep atmospheric nitrogen, and, so, integrate into the symbiotic community bonds [10]. This article first presents comparative results of the research related to the crop yield and other properties of different varieties of the broad bean in the temperate climate within organic farming. The main purpose of the article is to clarify what varieties of legumes can be effectively grown in the temperate climate zone, by virtue of which particular properties, and whether there is an advantage in their cultivation within organic farming. Among the planned tasks we have also investigated what varieties can be used as sources for breeding. The obtained data can be used for all Vicia faba L. populations in the temperate climate zone, since the territory, in which the researches have been carried out, has features that are standard for this climate zone (average annual temperature, humidity, etc.).

The objective of the present research is to evaluate the efficiency of the use of permaculture designs of various varieties of the broad bean (Vicia faba L.) and consider its positive and negative aspects for their application in permaculture farming.

\section{Material and Methods}

The research was conducted in 2014-2019 on the territory of the Moscow region (the Russian Federation) on the base of the Agrarian Division in the city of Moscow. The place, where the experimental part of the research has been conducted, is Educational Experimental Farm. As the research material, we selected 23 varieties of the broad bean from the collection of All-Russian Scientific-Research Institute of plant breeding and seed production (ARSRIPBSP) (Moscow), as well as foreign breeding. The territory, on which the seedlings were sown, was divided into two types (Fig. 1).

The first one included standard crops on farmland sown with the fruits of the broad bean (farm Pervomayskoe, Fig. 1). The second type included plots with natural vegetation, among which the same quantity of legumes was sown (farm Kurovo, Fig. 1). Thus, we were able to compare the efficiency and crop yield of beans on the plots of permaculture (organic farming) and standard cultures widely used in agriculture (the area under crops is expressed in square meters, $\mathrm{m}^{2}$ ).

The examined farms used different types of fertilizers (Table 1). Namely, the control farm (standard crops) utilized the benefits of manure and compost, while the experimental farm used green manure (incorporated into the soil before flowering) and microbial fertilizers.

So, the first group of plots belonged to the experimental ones, the second - to the control ones.

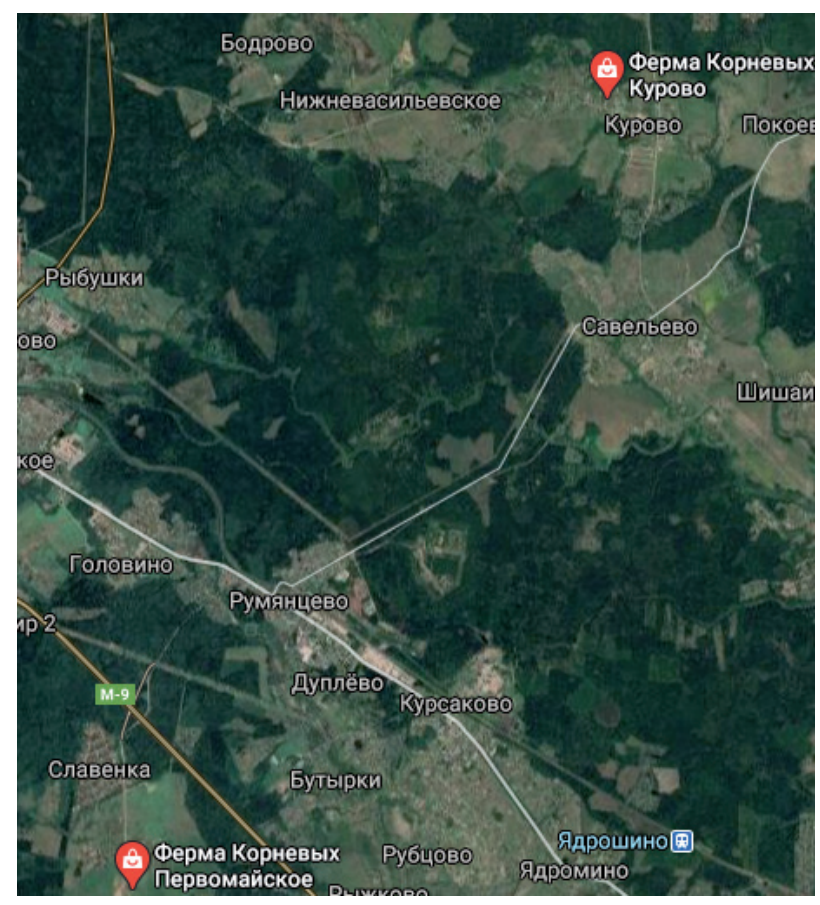

Fig. 1. Locations of farms growing standard (bottom left) and experimental (top right) cultures.

Sowing was carried out manually on plots of both types. In total, on the permaculture and control plots each variety was sown 5 times according to the 70 by $10 \mathrm{~cm}$ scheme, the sowing depth was $4-6 \mathrm{~cm}$. Thus, the total number of plots was 230 ones every year, 115 plots in the experimental and control groups each. For the period 2014-2019 the total number of plots was 1380, 690 each in the experimental and control groups. The area of one plot with crops is about 5 square meters. On 1 square meter, from 13 to 15 seeds were normally sown. The soil was previously hoed in the control and in the experimental parts, but without the removal of natural plant species in the experimental group.

The collection material was analyzed under the method of All-Russian Scientific-Research Institute of plant breeding named after N. Vavilov [11-13]. Besides, we have used the International classifier of COMECON Council for Mutual Economic Assistance of cultivated varieties for the genus Vicia faba L. [14], as well as the methodology of state variety testing of crops and the Methodology Guidelines for the use of the classifier for the genus Vicia faba L. [13].

The weather conditions (air humidity, air temperature, soil temperature and humidity) were estimated according to the meteorological data of

Table 1. Types of organic fertilizers used in the examined farms.

\begin{tabular}{|c|c|}
\hline Farm & Organic fertilizer \\
\hline Control & Compost, manure \\
\hline Experimental & Green manures, microbial fertilizers \\
\hline
\end{tabular}


the local station of the Institute of Meteorology of the Russian Academy of Sciences. Data is recorded automatically every 15 minutes, which gives extensive opportunities for their analysis. The data was taken during the growing season, from March to October 2014-2019.

Soils on the territory of both farms were sodpodzolic with an average humus content ranging from 2 to $4 \%$. This type of soil is most common in the Moscow region, occupying about $58 \%$ of its territory. Because the soils on one farm were identical to soils on another farm, it was possible to compare the crop yields obtained on both farm lands.

We defined the parameters such as the productivity of beans of various varieties in control and experimental groups. The productivity assumes the properties as the average quantity of beans per plant, quantity of seeds in the bean, the total weight of beans from one plant, as well as the weight of thousand seeds. In its turn, the weight of beans from the plant depends on the following properties such as the average weight of one bean and the quantity of technically ripe beans. The Belorussian varieties were taken as a standard.

To analyze the obtained data, the program Statistica v. 7.0 (StatSoft Inc.) was used. The graphs and tables show the values of the arithmetic mean and standard error of the mean, at a significance level of $p \leq 0.05$. In the text, there are the values of Pearson correlations. The accuracy of the discrepancies was checked using the standard Fisher test for independent sampling.

\section{Results and Discussion}

\section{The Duration of the Growing Season}

Data on the average monthly surface air temperatures and precipitation in the Moscow region are depicted in Figs 2a) and 2b). For a more complete picture of weather conditions, the figures illustrate how the average temperatures and precipitation levels changed across the seasons.

As it can be seen in Figs 2a) and 2b) above, the last two decades saw a steady increase in the average air temperature $\left(0.40 .6^{\circ} \mathrm{C}\right)$. Precipitation growth, however, was less prominent during the same period (3 to $36 \%$, with a high in spring).

We found out that the duration of the growing season determines the suitability of the beans' varieties for cultivation in a particular region. Among the factors influencing the parameter, the most important ones turned out the properties of the variety (correlation ratio with the duration of the growing season 0.91) and climatic conditions (0.85). According to the growing seasons among the specimens of beans of different varieties in the experimental and control groups, no significant differences were revealed. This suggests that in permaculture, within similar climatic conditions, growing seasons in duration are the same as in standard cultures.

Based on research outcomes we combined the varieties into two ripeness groups by the values of seeds' ripening. Medium early varieties are the ones with a ripening period of seeds $82-90$ days. The vast

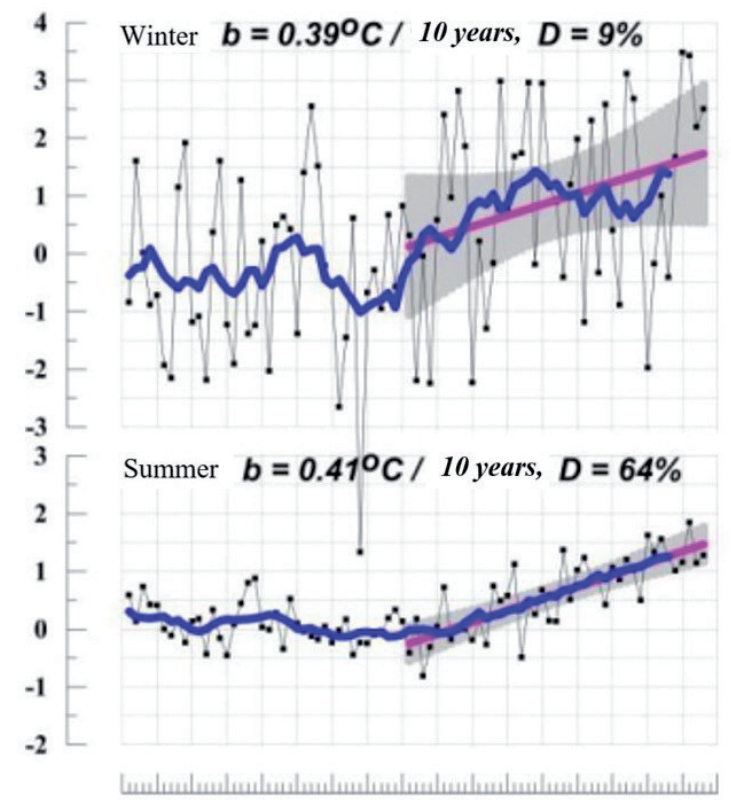

$19401950 \quad 1960 \quad 1970 \quad 19801990 \quad 2000 \quad 2010 \quad 2020$
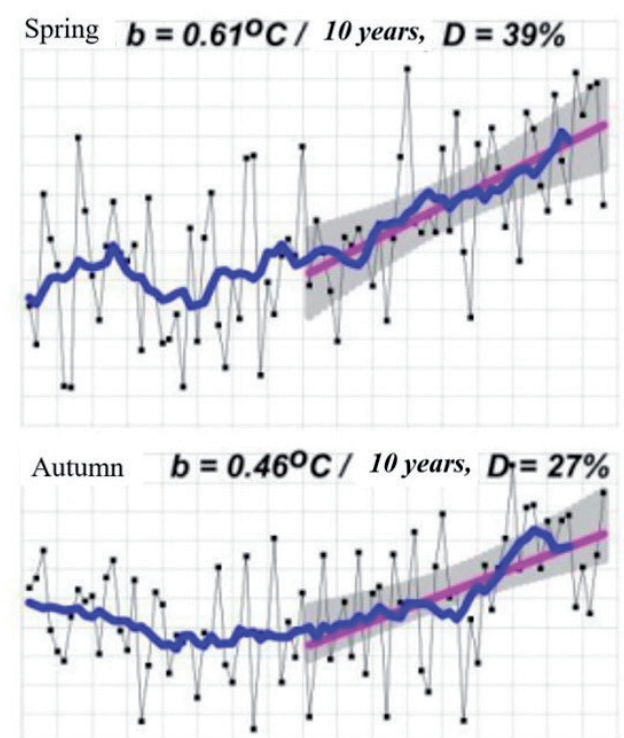

$194019501960 \quad 1970 \quad 19801990200020102020$

Fig. 2a). Average annual surface air temperatures (C): $b$ is the trend coefficient $\left({ }^{\circ} \mathrm{C} / 10\right.$ years), $D$ is the contribution to the total variance (\%). Available at: [27]. 

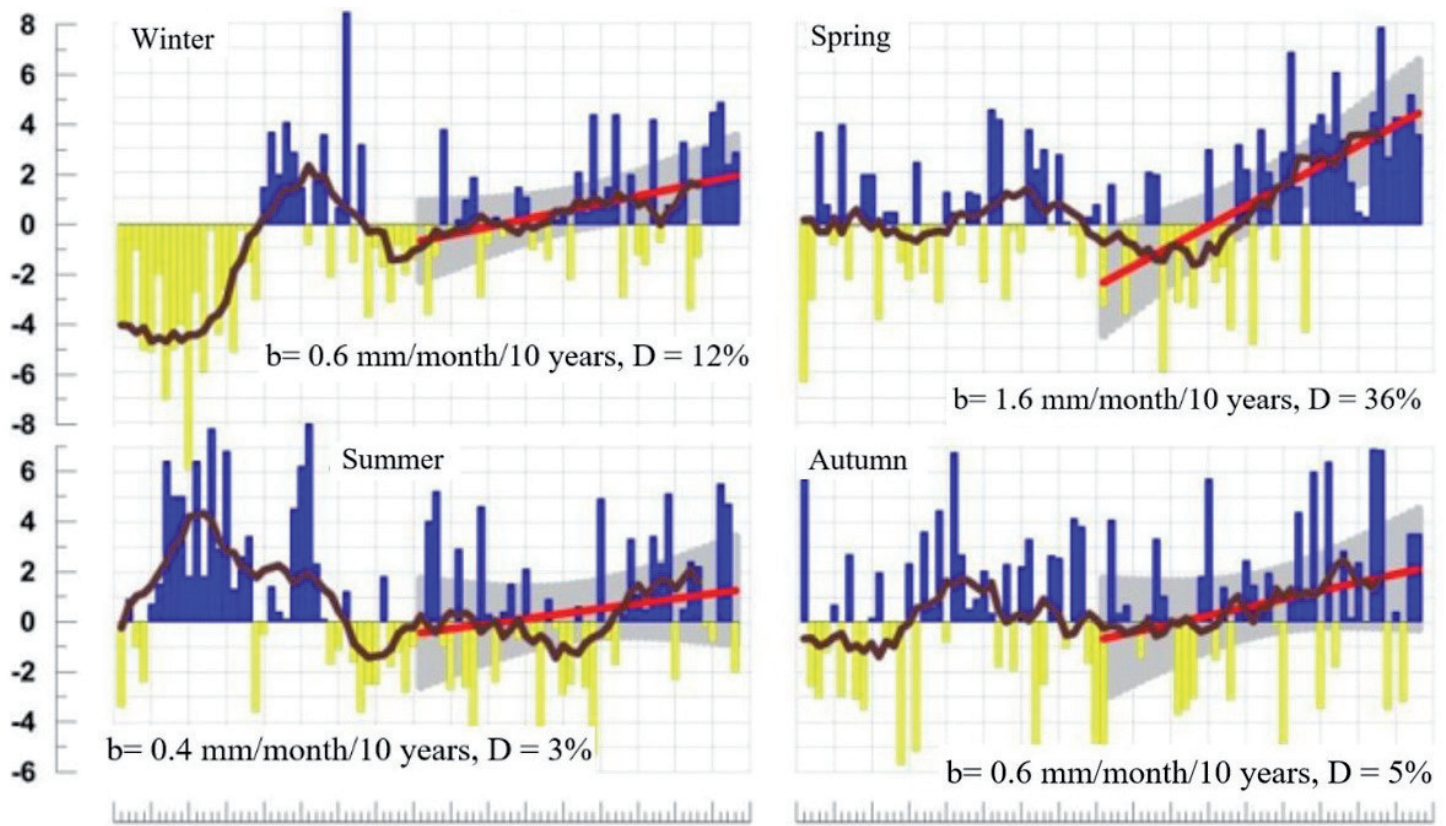

194019501960197019801990200020102020194019501960197019801990200020102020

Fig. 2b). Average annual precipitation: $b$ is the trend coefficient ( $\mathrm{mm} / \mathrm{month} / 10$ years), $D$ is the contribution to the total variance (\%). Available at: [27].

majority of varieties, which we have analyzed, in the quantity of 19 belongs to such seeds. The remaining 4 belong to mid-ripening varieties, with ripening periods of seeds from 91 to 110 days. Among the sources of early ripeness, we identified the following varieties: Russian black (95 days), Velena (91 days), Alfred (95 days), Merkur (95 days), Hangdown Grunkernig (97 days), Dreifach Weibe (95 days). For some varieties in the control and experimental groups, without statistically significant differences, a brief interphased period was recorded from the beginning of flowering to the technical ripeness of the beans: Belarusian (41 days), Russian black (47 days), Velena (47 days), K - 2267 (48 days) ), Hangdown Grunkernig (49 days), Dreifach Weibe (49 days), Mercur (47 days) and Alfred (48 days). During this growing season the crop yield occurs, as well as protein biosynthesis processes. In view of the data obtained, we recommend these varieties as sources for breeding of early ripening varieties.

As our data demonstrated that the more fast-ripening varieties turned out to be the following varieties of the beans: Russian black, Belarusian, Velena, as well as Merkur, Alfred, Hangdown Grunkernig, Dreifach Weibe.

Among the varieties considered, the average number of seeds per plant in the group of mid-ripening beans ranged from 7 to 30 pieces. In the mid-early group this parameter is slightly higher - from 5 to 57 pieces.

We have identified beans' varieties; quantity values of seeds that exceed the standard variety by $25-35 \%$ in the control group and by $22-31 \%$ in the experimental group (Table 2).

By the number of beans in both groups, the leader is the Russian black variety, which exceeds the rest

Table 2. Varieties of beans in control and experimental groups with a maximum quantity of beans (in pieces) for the period 2014-2019.

\begin{tabular}{|c|c|c|}
\hline Variety of beans, name & Quantity of beans, standard farming & Quantity of beans, organic farming \\
\hline Russian black & $30.1 \pm 3.7^{1,3}$ & $29.3 \pm 3.1^{2,3}$ \\
\hline Belarusian & $19.2 \pm 2.7$ & $20.1 \pm 3.0$ \\
\hline Merkur & $17.5 \pm 2.1^{1,3}$ & $17.8 \pm 1.8^{2,3}$ \\
\hline Velena & $16.8 \pm 1.4$ & $16.0 \pm 1.1$ \\
\hline Alfred & $15.6 \pm 1.6$ & $15.0 \pm 1.0$ \\
\hline Dreifach Weibe & $12.9 \pm 1.1$ & $12.6 \pm 0.9$ \\
\hline
\end{tabular}

Note: ${ }^{1}$ - significant differences between varieties Merkur, Russian black and other crop plants on control plots $(\mathrm{p} \leq 0.05) ;{ }^{2}-$ significant differences between varieties Merkur, Russian black and other crop plants on experimental plots $(\mathrm{p} \leq 0.05),{ }^{3}$ - significant differences between Merkur and Russian black within either of the two types of plots $(p \leq 0.01)$. 
Table 3. Varieties of beans in control and experimental groups with a maximum quantity of seeds from a plant (pieces) for the period 2014-2019.

\begin{tabular}{|c|c|c|}
\hline Variety of beans, name & Quantity of seeds, standard farming & Quantity of seeds, organic farming \\
\hline Alfred & $53.2 \pm 5.8$ & $49.0 \pm 4.8$ \\
\hline Merkur & $51.1 \pm 4.7$ & $48.6 \pm 4.8$ \\
\hline Belarusian & $49.4 \pm 3.2^{1,3}$ & $48.6 \pm 2.6^{2,3}$ \\
\hline Russian black & $42.3 \pm 3.5^{1,3}$ & $40.7 \pm 3.1^{2,3}$ \\
\hline K-1404 & $39.9 \pm 2.8$ & $39.0 \pm 2.6$ \\
\hline
\end{tabular}

Note: ${ }^{1}$ - significant differences between varieties Belarusian, Russian black and other crop plants on control plots ( $\left.\mathrm{p} \leq 0.05\right){ }^{2}-$ significant differences between varieties Belarusian, Russian black and other crop plants on experimental plots $(\mathrm{p} \leq 0.05),{ }^{3}-$ significant $^{2}$ differences between Belarusian and Russian black within either of the two types of plots $(\mathrm{p} \leq 0.05)$.

on the average 1.6-2.2 times $(\mathrm{p} \leq 0.05)$. There were no statistically significant differences between the groups. We can assume that the values of crop yield of beans' varieties in the control and experimental groups are identical in similar climatic conditions, although in the experimental group they are still somewhat lower (Table 2). According to the results obtained by us, the Russian black and Merkur varieties can be recommended as sources for breeding, a character is the number of beans from a plant.

The character of the seeds' quantity from a plant showed 1.5-2.0 times lower variation compared with the quantity of beans from a plant $(\mathrm{p} \leq 0.05$, Table 3$)$.

There are no statistically significant differences between control and experimental groups, although the crop yield in the control group in all cases is slightly higher. Between varieties, the quantity of seeds per plant is maximum at varieties Alfred (further - in descending order), Merkur and Belarusian, 0.5 times (at $\mathrm{p} \leq 0.05$ ) lower at Russian black and K-14-04.

The weight value of 1000 seeds is significantly different compared with the standard at the following varieties of beans (Table 4, Figs. 3 and 4): Velena,
Hangdown Grunkernig and Dreifach Weibe, minimum weight is specified at varieties K-2267, K-1800, Russian black.

Regardless of the fact that there is no significant difference in the weight under each variety between the control and the experiment, in the experimental group still the weight of 1000 seeds is lower in all cases. The difference between the control (Belarusian) and Velena, Hangdown Grunkernig, Dreifach Weibe on the one hand -0.5 times higher (at $\mathrm{p} \leq 0.05$ ), and with $\mathrm{K}-2267$, K-1800, Russian black - with another (at $\mathrm{p} \leq 0.001$ ), their weight 2.0-2.5 times less than the control.

Upon the value of the weight of seeds from a plant there were selected the following varieties: Belarusian $(35.7 \mathrm{~g})$, on the average the value of increase made up from 27.9 to $41.3 \mathrm{~g}$ from a plant, Russian black (36.1 g), from 14.1 to $57.2 \mathrm{~g}$ increase, Hangdown Grunkernig from $35.0 \mathrm{~g}$ (from 20.4 to $4.7 \mathrm{~g}$ increase), Merkur (32.5 $\mathrm{g}$, increase 21.0 to $40.3 \mathrm{~g}$ ), Alfed (27.6 g, increase from 16.0 to $40.0 \mathrm{~g})$, Dreifach Weibe $(25.1 \mathrm{~g}$, increase from 19.0 to $59.1 \mathrm{~g})$.

For the period, during which researches were conducted, the varieties, exceeded the control by the crop yield, received (Table 5).

Table 4. Weight of 1000 seeds (in grams, g) upon different varieties of seeds in control and experimental groups.

\begin{tabular}{|c|c|c|}
\hline Variety of beans, name & Weight of 1000 seeds, standard farming & Weight of 1000 seeds, organic farming \\
\hline Velena & $523.0 \pm 21.0^{1,3}$ & $511.4 \pm 20.6^{2,3}$ \\
\hline Hangdown Grunkernig & $502.4 \pm 19.3^{1,3}$ & $499.7 \pm 18.7^{2,3}$ \\
\hline Dreifach Weibe & $511.7 \pm 22.5^{1,3}$ & $509.1 \pm 20.1^{2,3}$ \\
\hline Belarusian & $445.4 \pm 16.4$ & $440.9 \pm 14.0$ \\
\hline K-2267 & $144.9 \pm 11.2$ & $140.8 \pm 10.6$ \\
\hline K-1800 & $140.0 \pm 10.6$ & $137.6 \pm 11.0$ \\
\hline Russian black & $162.6 \pm 12.7$ & $158.4 \pm 9.4$ \\
\hline
\end{tabular}

Note: ${ }^{1}$ - significant differences between varieties Velena, Hangdown Grunkernig, Dreifach Weibe and other crop plants on control plots $(\mathrm{p} \leq 0.05){ }^{2}$ - significant differences between varieties Velena, Hangdown Grunkernig, Dreifach Weibe and other crop plants on experimental plots $(\mathrm{p} \leq 0.05),{ }^{3}$ - significant differences between Velena, Hangdown Grunkernig, and Dreifach Weibe within either of the two types of plots $(\mathrm{p} \leq 0.05)$. 


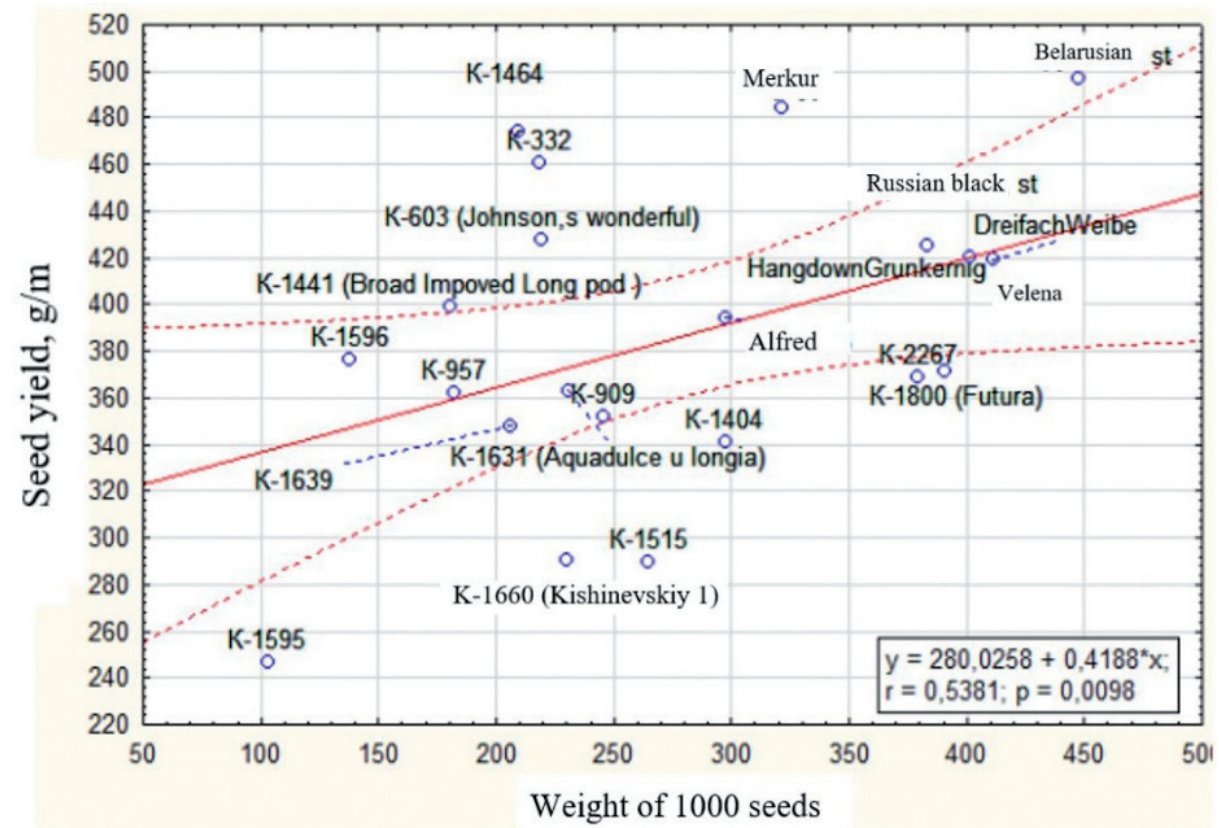

Fig. 3. Regression lines with a straightforward correlation between the average weight of 1000 seeds and plant yield, in 2014-2019.

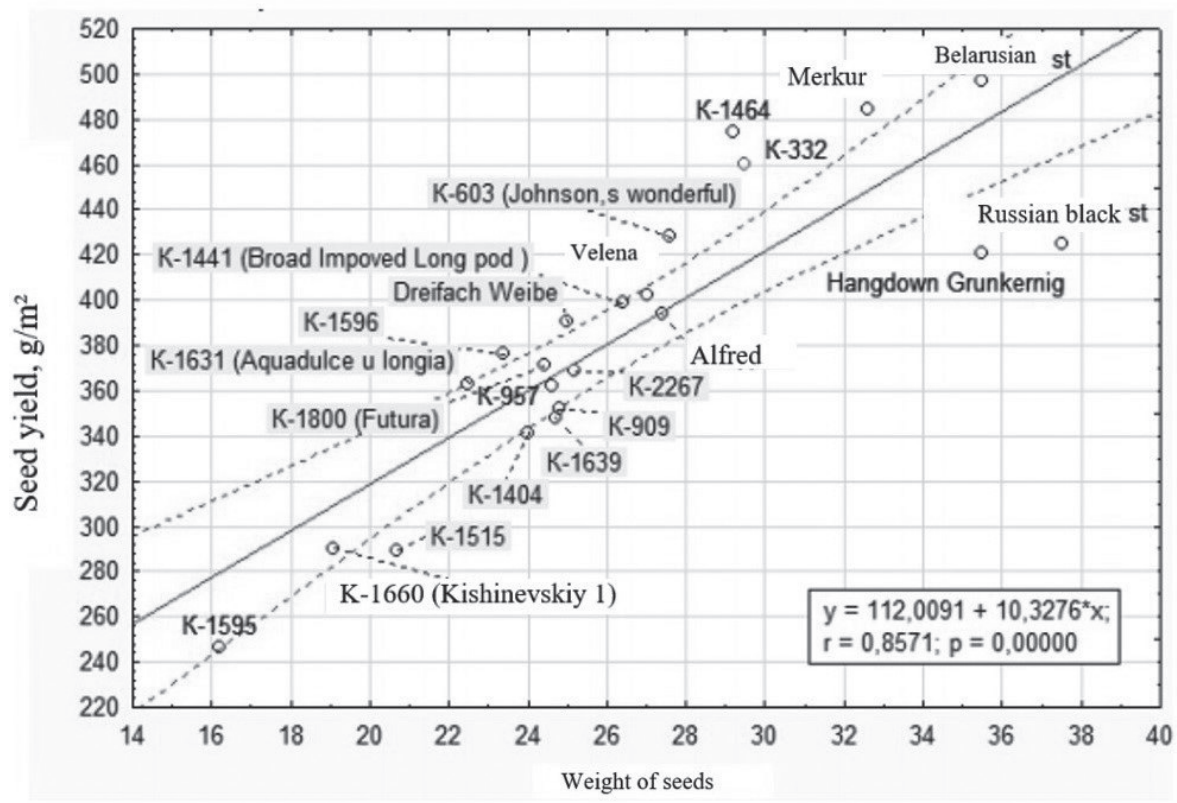

Fig. 4. Regression lines with a straightforward correlation between the weight of seeds from a plant and seed yield in 2014-2019.

The analysis of the results showed that for further breeding such varieties of beans as Belarusian, Russian black, Velena, Dreifach Weibe, Hangdown Grunkernig, Alfred and Merkur are suitable.

As we know, all basic principles of agriculture are related to soil properties [15]. In the soil, as a natural ecosystem, there is a set of species of algae, fungi, microorganisms that are peculiar for this type only and determine its properties, including fertility. The development of microorganisms is greatly influenced by the branching of the root system of plants.
The latter, in case of standard farming methods, and the use of many mineral and organic fertilizers, does not develop their root system properly. Legumes, in case of the use of nitrogen, do not develop their nodule system [16]. There is the decrease in the species diversity of microbiota. So, the processes of soil degumification are launched. To restore the soil that has lost such complex properties as fertility is cost and time consuming. You cannot collect the volumes of crop yields as they have been before from such soil [17]. In this regard, in the long term period, standard farming methods can lead to such consequences as desertification, and, if the 
Table 5. Selected varieties of beans, crop yield values of which are higher than standard ones $(p \leq 0.05)$ in organic agriculture group.

\begin{tabular}{|c|c|c|}
\hline Variety & Average crop yield value (in g per 1 $\mathrm{m}^{2}$ ) & Increase value (in $\mathrm{g}$ per $\left.1 \mathrm{~m}^{2}\right)$ \\
\hline Belarusian & $495.7 \pm 32.1$ & From 310 to 650 \\
\hline Hangdown Grunkernig & $630.8 \pm 55.9$ & From 300 to 640 \\
\hline Dreifach Weibe & $555.5 \pm 45.3$ & From 225 to 700 \\
\hline K-1464 & $475.0 \pm 39.0$ & From 315 to 630 \\
\hline Merkur & $486.4 \pm 37.4$ & From 220 to 660 \\
\hline K-332 & $465.0 \pm 43.1$ & From 190 to 550 \\
\hline Russian black & $430.5 \pm 23.9$ & From 125 to 820 \\
\hline
\end{tabular}

irrigation mode is not adequate, salinization of soils [18].

Organic farming does not imply critical changes in the composition of ecosystems, where standard cultures are prevailing, which is typical of standard methods [19]. At the same time, the permaculture covers a lot of species, including natural ones; therefore, there is no depletion of species diversity [20]. Pesticides and fertilizers are not used, there is no plowing of land with subsequent disruption of water exchange processes and mineralization [21]. Based on our data there is no or statistically insignificant (at least for temperate regions) difference in the yield of seeds and beans. Thus, we can state that the permaculture is suitable for growing a broad bean. At the same time, permacultures are not characterized by the scale, with which standard cultures are grown in traditional agriculture [22]. Many smallholder farms in the aggregate can cover the growing needs of the society in farming products [23]. Apart from benefits originating in the inviolability of biocenoses, we should mention about a large assortment of products supplied to the global market by farms that use permaculture. Instead of a single standard culture, many varieties and species of agricultural plants are grown in the best quality [24]. Such examples are known, and the results obtained on different crops are similar to ours - a slightly lower crop yield, but essential benefits in the long term period [25]. Permacultures, among other things, do not require mechanical cultivation of the land, which results in fuel economy and technical capacities.

A large diversity of permacultures implies their lower susceptibility to various pests. The latter for a short period of time (one or two seasons) is able to create centers of mass reproduction and destroy a significant part of the crop in standard cultures. The permacultures, including legumes and other crops, due to their immunity, will not be affected by pests on such a scale [26]. The preservation of natural ecosystems will also ensure the presence of natural enemies of pests, which often also die in large quantities, when standard cultures are treated with pesticides and insecticides.

We have demonstrated that in the conditions closed to natural ones some varieties of beans can give the same yield as under standard farming. However, the research needs to be continued in terms of isolation of new varieties of legumes suitable for breeding and cultivation under permaculture.

\section{Conclusions}

On analyzing the productivity (weight of 1000 seeds, quantity of seeds per plant, number of beans, their maximum values) and crop yield for each variety, there is no significant difference between the control (standard farming methods) and experiment (permaculture). It enables to cultivate a broad bean in permaculture. The seed yield in both groups is related to the quantity of beans, as well as the weight of seeds from a plant, bean yield is related to their weight. For these properties Pearson 0.7 correlation ratios were obtained. The breeding of beans for crop yield, including organic farming (permaculture) is associated with the values such as the weight and quantity of seeds per plant.

\section{Acknowledgements}

The authors are most grateful to the reviewer who provided useful comments on an earlier version of the manuscript.

\section{Conflict of Interest}

The authors declare no conflict of interest.

\section{References}

1. SALLEH A.M., ROSLI F.M., ESA N., IBRAHIM M.H. Permaculture Design: Linking Local Knowledge in Land Use Planning for House Compound. SHS Web Conf. 45, 03003, 2018.

2. De TOMBEUR F., SOHY V., CHENU C., CORNÉlIS J.T. Permaculture practices favor organic matter storage in labile form in the macroaggregate pool. EGU General Assem. Conf. Abstract. 20, 4333, 2018. 
3. HIRSCHFELD S., VAN ACKER R. Permaculture farmers consistently cultivate perennials, crop diversity, landscape heterogeneity and nature conservation. Renew. Agric. Food Syst. 1, 1, 2019.

4. VITARI C., DAVID C. Sustainable management models: innovating through Permaculture. J. Manag. Dev. 36 (1), 14, 2017.

5. AKHTAR F., LODHI S.A., KHAN S.S., SARWAR F. Incorporating permaculture and strategic management for sustainable ecological resource management. J. Environ. Manag. 179, 31, 2016.

6. SYMANCZIK S., GISLER M., THONAR C., SCHLAEPPI K., VAN DER HEIJDEN M., KAHMEN A., BOLLER T., MÄDER P. Application of Mycorrhiza and Soil from a Permaculture System Improved Phosphorus Acquisition in Naranjilla. Front. Plant. Sci. 8, 1263, 2017.

7. HATHAWAY M.D. Agroecology and permaculture: addressing key ecological problems by rethinking and redesigning agricultural systems. J. Environ. Stud. Sci. 6 (2), 239, 2016

8. De TOMBEUR F., SOHY V., CHENU C., COLINET G., CORNELIS J. T. Effects of permaculture practices on soil physico-chemical properties and organic matter distribution in aggregates: A case study of the BecHellouin farm (France). Front. Environ. Sci. 6, 116, 2018.

9. UDOMKUN P., TIRAWATTANAWANICH C., ILUKOR J., SRIDONPAI P., NJUKWE E., NIMBONA P., VANLAUWE B. Promoting the use of locally produced crops in making cereal-legume-based composite flours: An assessment of nutrient, antinutrient, mineral molar ratios, and aflatoxin content. Food Chem. 286, 651, 2019.

10. 10. SHARMA A. Antinutritional factors as influenced by processing parameters during the production of some traditional legume based fermented foods of India. University of North Bengal: Siliguri, India, 2017.

11. BEZUGLOVA Ye.V. The source material for the selection of beans (Vicia faba) and the effect of biological preparations on their economically valuable traits in the southern forest-steppe of Western Siberia. Dissertation. Tyumen State Agricultural Academy: Tyumen, Russia, 2015.

12. BULYNTSEV S.V., TIELIKH K.M. New varieties of vegetable and fodder beans, developed on the basis of the collection of All-Russian Scientific-Research Institute of plant breeding named after N. Vavilov. In Means of increasing the efficiency of the use of genetic resources of leguminous crops in selection. Materials International Scientific Conference: St. Petersburg, Russia, pp. 22-23, 2016.

13. METHODOLOGY GUIDELINES. Methodology Guidelines for the use of the classifier for the genus Vicia faba L. (beans). All-Russian Scientific-Research Institute of plant breeding named after N. Vavilov: Leningrad, Russia, 1980.

14. BUDANOVA V. International classifier COMECON Council for Mutual Economic Assistance of cultural species genus Phaseolus L. All-Russian ScientificResearch Institute of plant breeding named after $\mathrm{N}$. Vavilov: Leningrad, Russia, 1985.

15. PINELA J., PETROPOULOS S.A., FERREIRA I.C.F.R. Innovative Legume Foods. In Legumes: Nutritional Quality, Processing and Potential Health Benefits. MartínCabrejas M. A., Ed., Royal Society of Chemistry: London, United Kingdom, 235, 2018.
16. SPARVOLI F., LAUREATI M., PILU R., PAGLIARINI E., TOSCHI I., GIUBERTI G., FORTUNATI P., DAMINATI MG., COMINELLI E., BOLLINI R. Exploitation of common bean flours with low antinutrient content for making nutritionally enhanced biscuits. Front. Plant Sci. 7, 928, 2016.

17. KAUSHIK G., SINGHAL P., CHATURVEDI S. Food Processing for Increasing Consumption: The Case of Legumes. In: Food Processing for Increased Quality and Consumption. Academic Press: San Diego, USA, pp. 1-28, 2018.

18. SMITH L.G., LAMPKIN N.H. Greener farming: managing carbon and nitrogen cycles to reduce greenhouse gas emissions from agriculture. Managing Global Warming. Academic Press: San Diego, USA, pp. 553-577, 2019.

19. ROBERTS E. Agroforestry for the Northeastern United States: research, practice, and possibilities. In Integrating Landscapes: Agroforestry for Biodiversity Conservation and Food Sovereignty Montagnini F. Ed., Springer: Cham, Switzerland, pp. 79-126, 2017.

20. NIEDER R., BENBI D. K., REICHL F. X. Macro-and Secondary Elements and Their Role in Human Health. In Soil Components and Human Health. Springer: Dordrecht, Netherlands, pp. 257-315, 2018.

21. ŚREDNICKA-TOBER D., BARAŃSKI M., SEAL C., SANDERSON R., BENBROOK C., STEINSHAMN H., GROMADZKA-OSTROWSKA J., REMBIAŁKOWSKA E., SKWARŁOSOŃTA K., EYRE M., COZZI G., LARSEN M.K., JORDON T., NIGGLI U., SAKOWSKI T., CALDER P.C., BURDGE G.C., SOTIRAKI S., STEFANAKIS A., YOL-CU H., STERGIADIS S., CHATZIDIMITRIOU E., BUTLER G., STEWART G., LEIFERT C. Composition differences between organic and conventional meat; a systematic literature review and meta-analysis. Br. J. Nutr. 115 (6), 994, 2016.

22. DE SCHUTTER O. UN Special Rapporteur on the right to food. Report on agroecology and the right to food, 2014. Available online: http://www2.ohchr.org/english/issues/ food/docs/A-HRC-16-49.pdf (Accessed 10 June 2020).

23. SEMEDO M.H. Agriculture should be integrated in climate change policies, 2017. Available online: http:// www.fao.org/members-gateway/news/detail/en/c/357972/ (Accessed 10 June 2020).

24. PONISIO L.C., M'GONIGLE L.K., MACE K.C., PALOMINO J., DE VALPINE P., KREMEN C. Diversification practices reduce organic to conventional yield gap. P. Roy. Soc. B-Biol. Sci. 282 (1799), 20141396, 2014.

25. THE ROCKEFELLER FOUNDATION. Waste and spoil again the food chain. Decision Intelligence Document, 2013. Available online: https://www.rockefellerfoundation. org/wp-content/uploads/Waste-and-Spoilage-in-the-FoodChain.pdf (Accessed 10 June 2020).

26. GUSTAVSSON J., CEDERBERG C., SONESSON U., VANOTTERDIJK R., MEYBECK A. Global food losses and food waste - Extent, causes and prevention. FAO: Rome, Italy, 2011.

27. FEDERAL SERVICE FOR HYDROMETEOROLOGY AND ENVIRONMENTAL MONITORING (ROSHYDROMET). Report on the Specific Features of the Climate in the Territory of the Russian Federation for 2018. Moscow, 2019. Available online: https://meteoinfo. ru/images/media/climate/rus-clim-annual-report.pdf 
